\title{
Infografia: Conceito e Prática
}

\author{
Infographics: Concept and Practice
}

Juliana Carvalho, Isabella Aragão

design gráfico, linguagem visual, infografia, metodologia

O designer gráfico tem o desafio de desenvolver artefatos capazes de transmitir diferentes tipos de informações. São periódicos, cartazes, identidades visuais, embalagens e, entre tantos outros, infográficos. A infografia foi escolhida como foco deste trabalho, que faz um levantamento bibliográfico sobre os aspectos fundamentais da infografia e do design, relacionando-os a partir da possibilidade de tratar o infográfico como um artefato de design, configurado através da linguagem visual. Propõe-se, ainda, a indicar uma maneira de produzir infográficos, a partir da prática de profissionais contemporâneos.

graphic design, visual language, infographic, methodology

Graphic designer has the challenge of developing devices capable of transmitting different types of information, such as books, magazines, posters, brands, packages and, among others, infographics. Infographics is the subject of this paper, which proposes a literature review of fundamental aspects from graphic design and infographics, relating them from the possibility of treating this object as a design artefact, configured through visual language. It also proposes a methodological approach to creating static infographics, based on interviews with contemporary working professionals.

\section{Introdução}

Apesar de ser uma atividade conferida a designers, a infografia é tratada mais frequentemente sob uma perspectiva jornalística. Tem seu uso voltado à comunicação e seus contextos de aplicação (jornais, revistas e demais mídias impressas ou digitais), devido à própria natureza informacional dos infográficos. Entretanto, seus estudos pouco abordam os elementos essenciais da linguagem visual. A escassez de abordagem conceitual específica entre design gráfico e infografia (apesar de serem temas visivelmente próximos) na literatura, valida e incentiva um estudo que relaciona os dois temas.

Esta pesquisa objetiva desenvolver uma metodologia para criação de infográficos estáticos, baseada na observação da prática de profissionais da área e em conceitos teóricos. Para tal, definiu-se como objetivos específicos: (1) Realizar uma revisão bibliográfica sobre linguagem visual e infografia, relacionando autores e conceitos; (2) Propor uma conceituação baseada nos princípios do design gráfico; (3) Examinar os elementos gráficos que compõem o infográfico; (4) Entrevistar profissionais da área; (5) Criar um infográfico sobre a própria pesquisa.

Pretende-se, portanto, enriquecer o conhecimento sobre infográficos, a partir dos conhecimentos do design, aprofundando um campo de estudos que ainda é fundamentalmente ligado à prática.

\section{Infografia e linguagem visual}

Há diversas formas de conceituar a infografia, entretanto, a definição mais fundamental parte do próprio significado da palavra. Ribeiro (2008) afirma que a expressão vem do termo inglês infographic, uma redução de information graphic, que significa informação gráfica. Em português, o termo "grafia" denota escrita ou registro e "info" remete a informação. Desta construção, diz-se que infográfico é "informação + gráfico", geralmente interpretado como uma imagem acompanhada de texto. Para De Pablos, 
A infografia é a apresentação impressa de um binômio imagem + texto $(b \mid+T)$, qualquer que seja o suporte onde se apresenta essa união informativa: tela, papel, plástico, barro, pergaminho,papiro, pedra. (De Pablos, 1999:19).

Apesar desta interpretação não ser totalmente falsa, deixa margens a uma abordagem ampla, na qual qualquer imagem acompanhada de texto pode ser caracterizada como infográfico. Devese observar que o teor do conteúdo transmitido é importante para uma caracterização. Rajamanickam descreve,

Construir a representação visual da informação não é mera tradução daquilo que pode ser lido para aquilo que pode ser visto. Implica filtragem da informação, estabelecer relações, diferenciar padrões e representá-los de uma forma que permitam ao leitor compreender que tal informação constrói algo com significado. (Rajamanickam, 2005:2).

Tal descrição explica de forma mais completa a ligação entre representação da informação e o infográfico, entretanto, não o define. A fim de compreendê-lo como um sistema mais complexo que relaciona conteúdo com representação da informação, convém abordar outros dois temas: linguagem visual e gráficos.

Perceber o infográfico como linguagem visual leva a entender as formas de configurar seus conteúdos. Com a definição e a função dos gráficos, é possível entender a função da infografia. Os próximos tópicos abordam as definições destes temas.

\subsection{A linguagem visual}

A lingüística é o campo de estudo que desenvolveu um instrumental teórico voltado para o entendimento da linguagem verbal. No design, vários autores fazem uso deste instrumental, como Horn (1998) e Twyman (1979), que adequaram os conceitos da lingüística para o estudo da linguagem visual e linguagem gráfica, respectivamente. Ambos desenvolveram hipóteses que vem sendo aplicadas em diversas áreas do design gráfico. Para classificar o infográfico como objeto de design, faz sentido estudá-lo, também, como a linguagem é utilizada nele.

Segundo Twyman (1979), a linguagem é definida como um veículo de comunicação. Pode ser auditivo (verbal ou não-verbal) ou visual (gráfico ou não-gráfico), classificação baseada no canal e no modo de representação da linguagem. Já o gráfico é qualquer elemento feito visível através de uma ação consciente. A linguagem gráfica, portanto, é composta por marcas produzidas com a intenção de comunicar uma mensagem. Ela pode ser representada por modos de simbolização verbal, pictórica e/ou esquemática (figura 1).

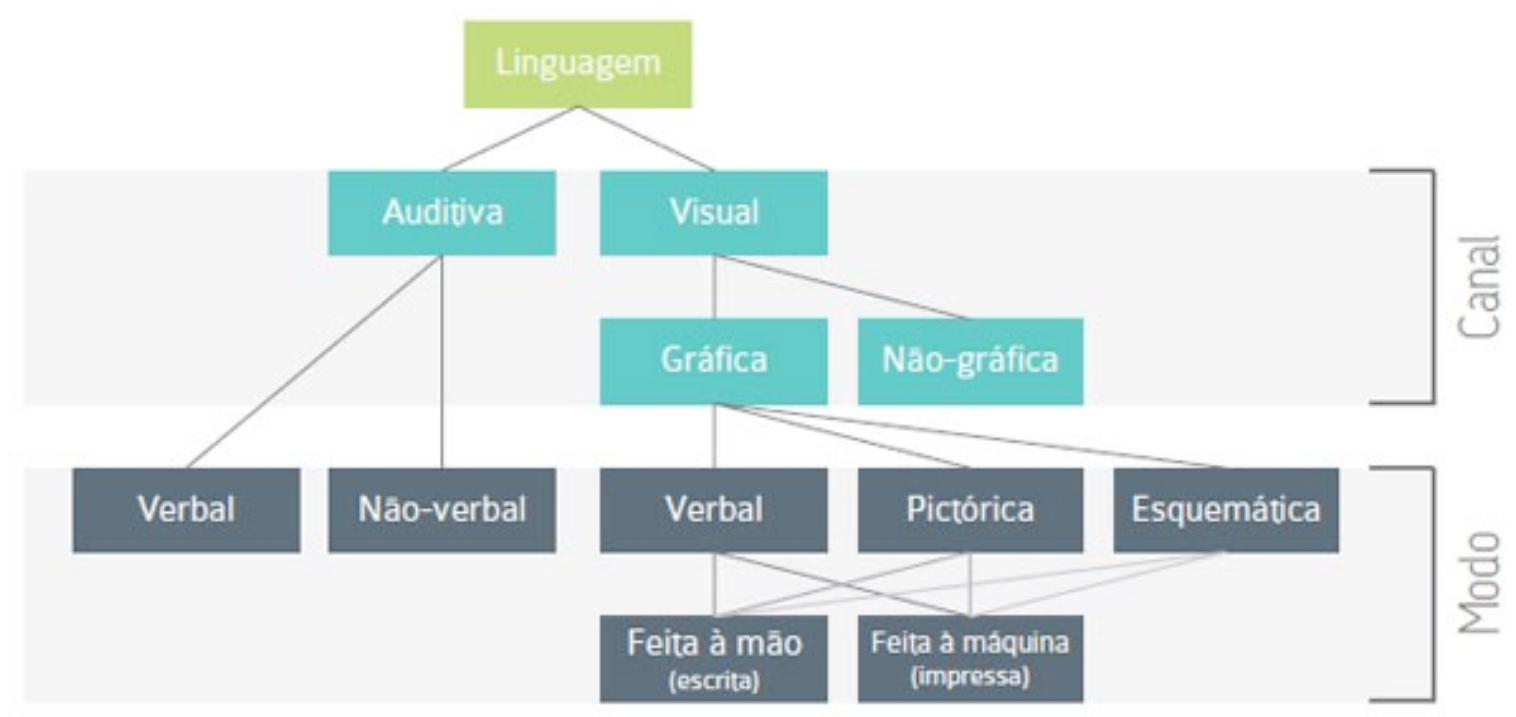


Para Horn (1998), a linguagem visual resulta da interação entre lingüística e elementos visuais. O autor faz uso de três elementos para realizar esta interação: texto, imagem e forma (figura 2). Classifica, ainda, estes três elementos como elementos verbais (texto) e elementos visuais (imagem e forma). Textos dão um formato conceitual à comunicação, além de possuir a capacidade de nomear, definir e classificar elementos, podem ainda discutir abstrações; imagens são representações gráficas da realidade e formas se diferenciam das imagens por serem mais abstratas.

Figura 2: Exemplos elementos gráficos, baseados na definição de Horn (1998) sobre texto, imagem e forma.

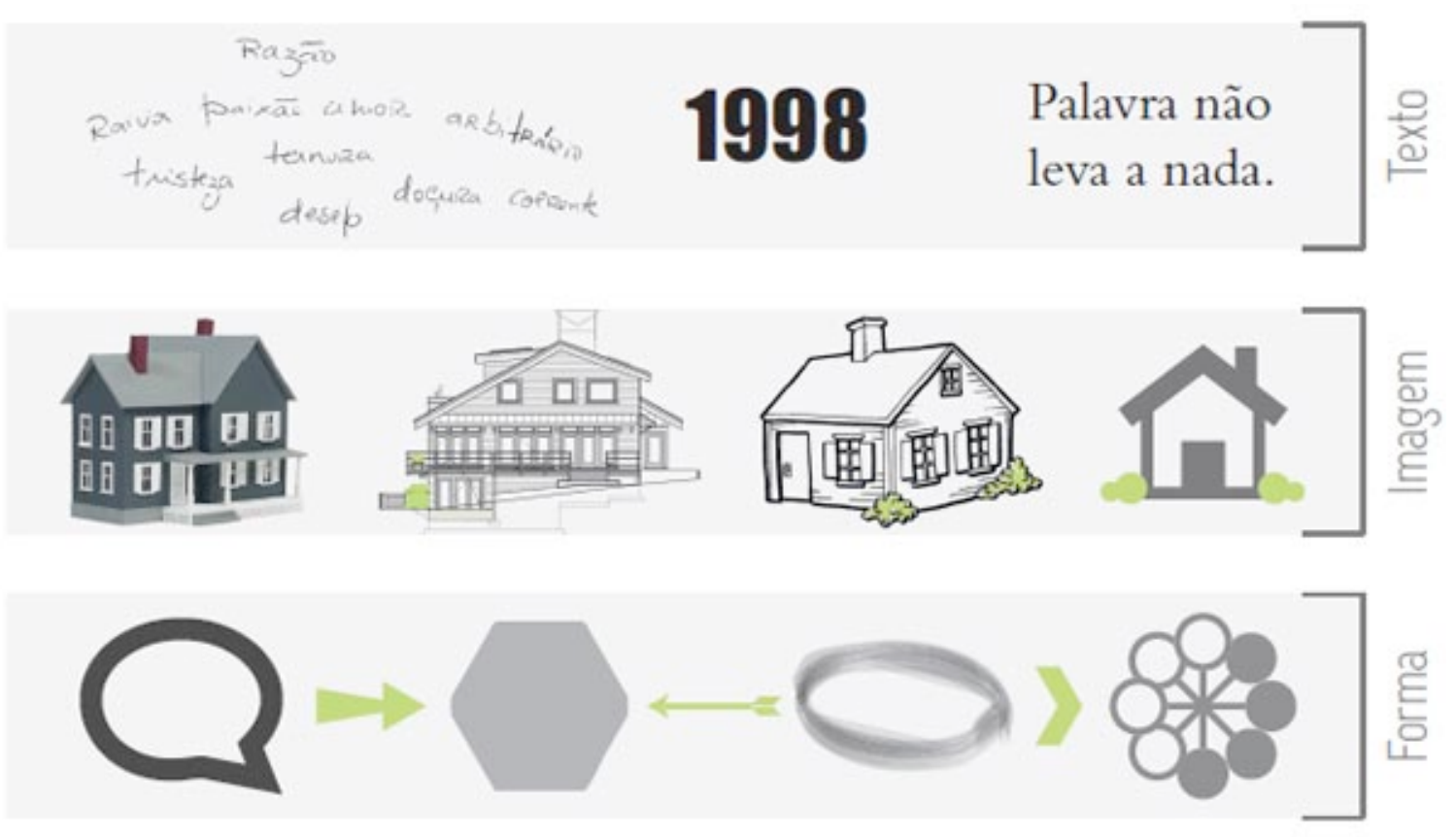

A classificação de linguagem gráfica de Twyman (1979) associada à proposição de Horn (1998), culmina no entendimento fundamental sobre linguagem visual. Tal entendimento se mostra bastante relevante quando levado à infografia, uma vez que os elementos gráficos estudados pelos autores citados acima permeiam seus artefatos. No intuito de definir a infografia a partir dos conceitos de linguagem, convém comparar os autores citados anteriormente.

Os três elementos que compõe a linguagem visual para Horn (1998), muito se assemelham à classificação de linguagem gráfica proposta por Twyman (1979). A linguagem verbal sendo a representação gráfica da linguagem falada, pode ser interpretada como texto. A visual pictórica é composta por reproduções de imagens, e equivale à descrição de imagem dada por Horn (1998). A visual esquemática, como formas gráficas que não incluem palavras ou imagens, se adequa a forma também proposta por Horn (1998). A principal diferença entre as abordagens dos autores, se dá no argumento apresentado por Horn (1998). O autor define que textos, imagens ou formas sozinhas não compõem linguagem visual. $O$ texto comunica, mas não visualmente. Formas são visuais, mas não comunicam nada sozinhas. Imagens descontextualizadas são visuais, mas sua comunicação é artística.

A integração de texto, imagens e formas em uma única unidade de comunicação e/ ou o uso de texto e imagens ou texto e formas para compor uma única unidade de comunicação definem a linguagem visual (Horn,1998:8). Aqui, o termo linguagem visual será utilizado para expressar o entendimento de linguagem baseado na conversão de conceitos presentes na obra de Horn (1998) e de Twyman (1979).

Não é recente a associação da linguagem visual com o conceito de infografia. Até mesmo Horn (1998:55) a define como uma das unidades de comunicação da linguagem visual. Esta classificação do autor é feita a partir das relações entre os elementos gráficos e da proporção física de cada peça. Do ponto de vista de Horn (ibid.), os infográficos são peças que possuem certa complexidade e tamanho, se comparada às demais unidades de comunicação. Geralmente 
apresentam um elemento visual (ou um conjunto deles) central, acompanhados de diversos blocos de textos explicativos. O infográfico é considerado uma unidade de comunicação autônoma, pois seu entendimento não depende de um contexto (Horn, 1998).

Esta conceituação é bastante esclarecedora no sentido de já considerar infografia como lingugem visual, mas ainda não é específica o suficiente, por não abranger as características de conteúdo, e entender o tamanho da peça como fator determinante para a classificação.

Sendo um infográfico um objeto passível de leitura, que combina os três elementos fundamentais da linguagem visual, convém adotar infografia como tal. Desta relação, agregam-se os mesmos conceitos definidores da linguagem à atividade. Utilizando os parâmetros definidos por Horn (1998) e Twyman (1979), o infográfico é um artefato produzido no intuito de comunicar uma mensagem. Essa mensagem é transmitida através da integração de texto, imagens e/ou formas.

Esta é uma perspectiva capaz de descrever com mais profundidade o que caracteriza a infografia. Entretanto, ainda seria possível classificar uma imagem acompanhada de texto como infográfico. A análise do conteúdo da infografia é um fator capaz de diferenciar o infográfico e outras peças gráficas. Portanto, se faz necessário entender algumas configurações comumente utilizadas neste artefato de comunicação: os gráficos.

\subsection{Gráficos}

Tufte (2001) aborda no livro The visual display of quantitative information a conversão de dados em gráficos. Para o autor, "gráficos revelam dados. Na verdade os gráficos podem ser mais precisos e reveladores do que os convencionais cálculos estatísticos" (Tufte, 2001:13).

Tufte (ibid.) defende que os gráficos são os melhores instrumentos para raciocinar sobre informações quantitativas. É possível descrever, explorar e resumir um conjunto de números e dados através das imagens deles. A partir destas informações, define-se como função dos gráficos contextualizar visualmente uma interpretação de dados. Agregando essa funcionalidade aos infográficos, e incorporando-a ao conceito dado a infografia no tópico anterior, chega-se a um novo conceito, ainda preliminar: Infográfico é um artefato produzido no intuito de comunicar uma mensagem, que resulta de uma interpretação de dados contextualizados visualmente através da integração de texto, imagens e/ou formas.

Nota-se que diversos autores determinaram o que vem a ser um infográfico, utilizando um determinado viés, seja de aparência, tamanho ou conteúdo. Da perspectiva descrita acima, há uma limitação um pouco maior do que é tido ou não como infografia. Porém, é importante, para este trabalho, não só a relação entre imagem e texto ou uma caracterização espacial, mas sim aspectos que relacionam forma e conteúdo. 


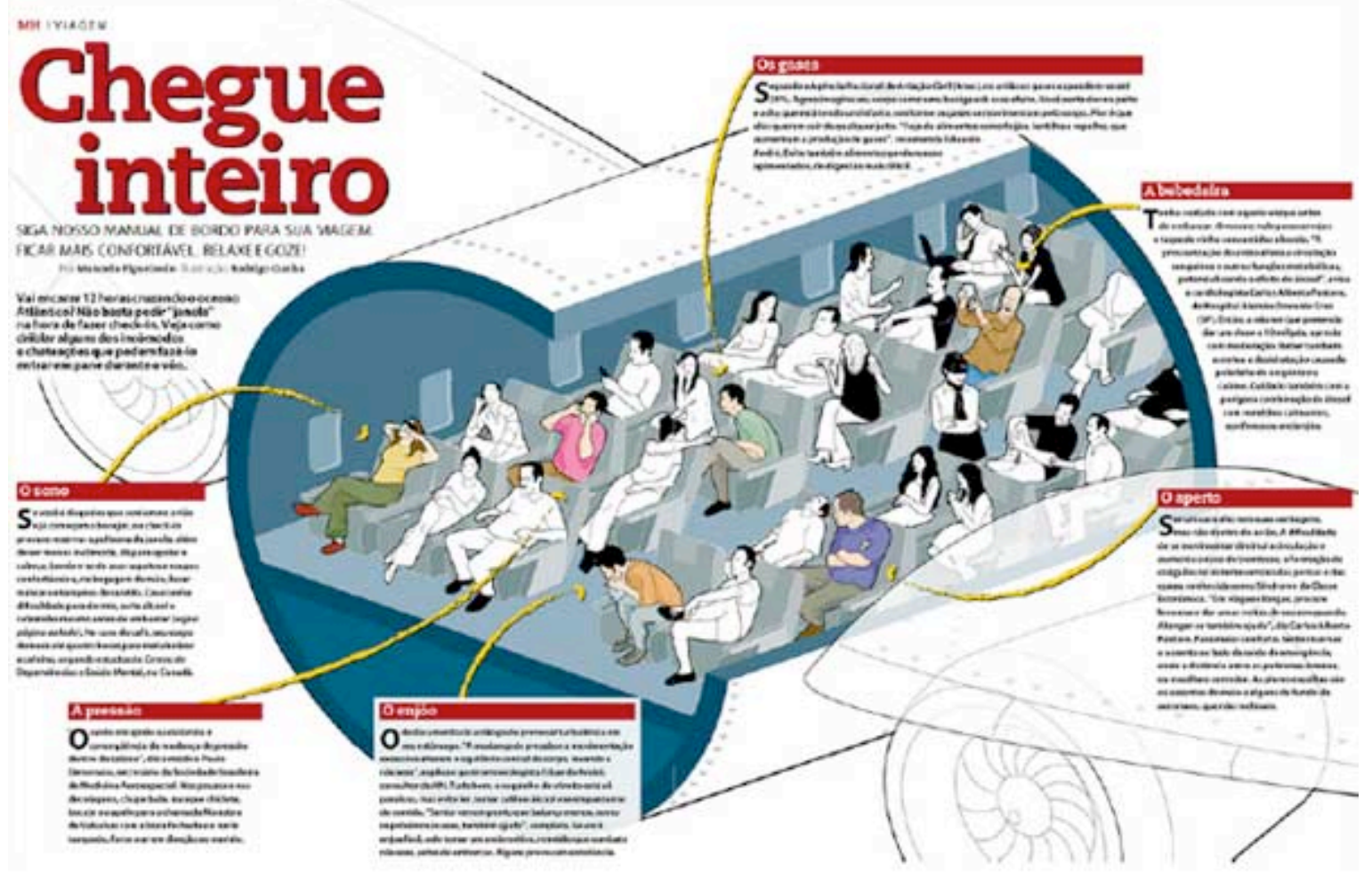

Na figura 3, é possível notar que através de uso da imagem (perspectiva do avião e personagens), texto (títulos, introdução e blocos de texto) e forma (setas), transmite-se uma idéia, um contexto narrativo, capaz de configurar um tipo de informação que o infográfico tem a função de transmitir. Parte-se, portanto, para o estudo desses tipos. O conhecimento de tipologias colabora na construção do conceito procurado nesta pesquisa.

\subsection{Tipologias}

Os gráficos explorados pela infografia, são, portanto, dados já interpretados. Diversos autores propõe classificação desses gráficos, levando em consideração e teor do conteúdo, como Tufte (2001) e Rajamanickam (2005).

Tufte (2001) defende que infográficos são configurados em desenhos gráficos fundamentais:

- Mapas - as informações estão interligadas a fronteiras, formas e áreas geográficas.

- Séries de tempo - lida com a ordenação natural de escalas de tempo. Permite comparações entre momentos da escala escolhida - segundos, minutos, horas, dias, semanas, meses, etc.

- Narrativos de espaço-tempo - explanam acontecimentos que se movem no espaço (bi ou tridimensional) e no tempo.

- Gráficos relacionais - consiste em relacionar duas variáveis em um mesmo gráfico, com plano cartesiano $(x$ e $y$ ) ou medidas abstratas.

Assim como Tufte (2001), Rajamanickam (2005) desenvolveu uma tipologia baseada no conteúdo informacional dos infográficos. Além do tipo de informação contida no artefato, o autor leva em consideração as formas de representá-la, sintetizando infografia em três variáveis: tipo da 
informação, ferramenta de representação e método de comunicação. A figura 4 ilustra a abordagem proposta por Rajamanickam (ibid.). Esta síntese é interessante, pois relaciona forma, conteúdo e a mídia na qual será veículada.

Figura 4: Tipologia de infográficos proposta por Rajamanickam (2005).
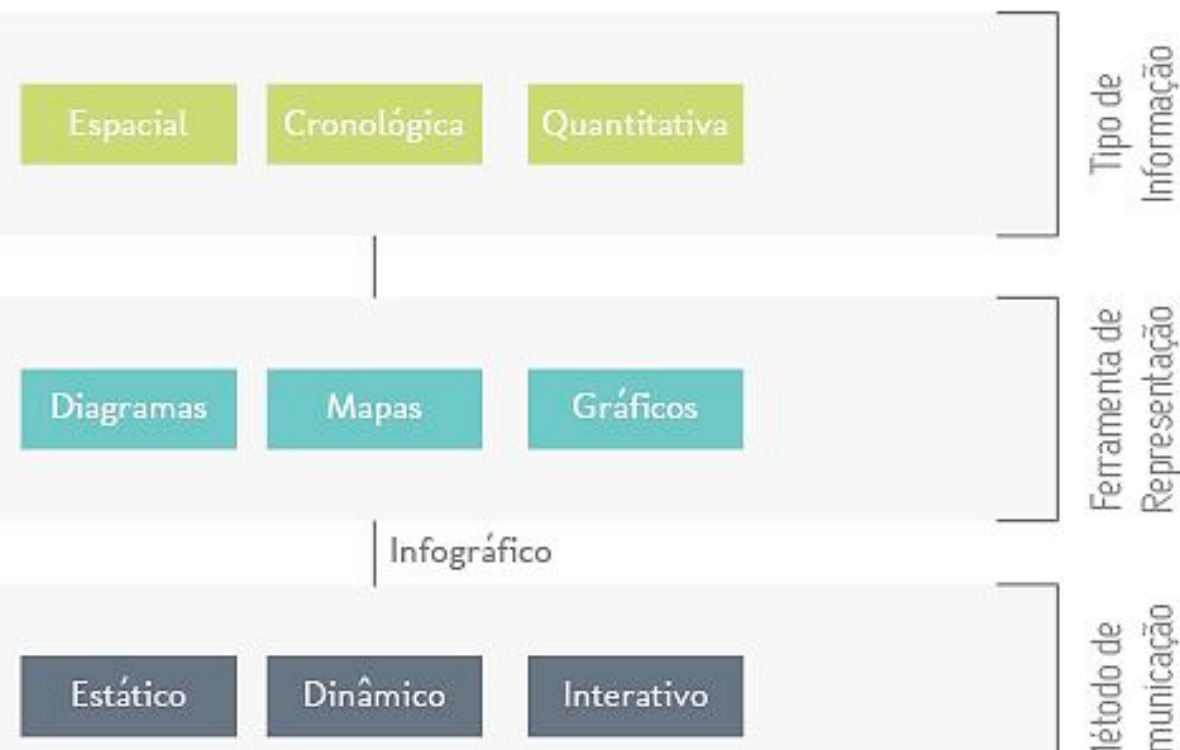

Enquanto Tufte (2001) propõe formas mais genéricas de configurar determinadas informações, Rajamanickam (2005) propõe uma tipologia um pouco mais completa, por fazer uma indicação sobre o tipo de informação e as formas de representá-la.

A maior semelhança entre as duas tipologias é encontrada ao comparar "tipo de informação" proposto por Rajamanickam (2005) e a os desenhos fundamentais de Tufte (2001). Fica clara nesta comparação (figura 5) a existência de três tipos comuns entre si, e um sobressalente:

Figura 5: Comparação entre tipologia de Tufte (2001) e de "tipos de informação" sugeridas por Rajamanickam (2005).

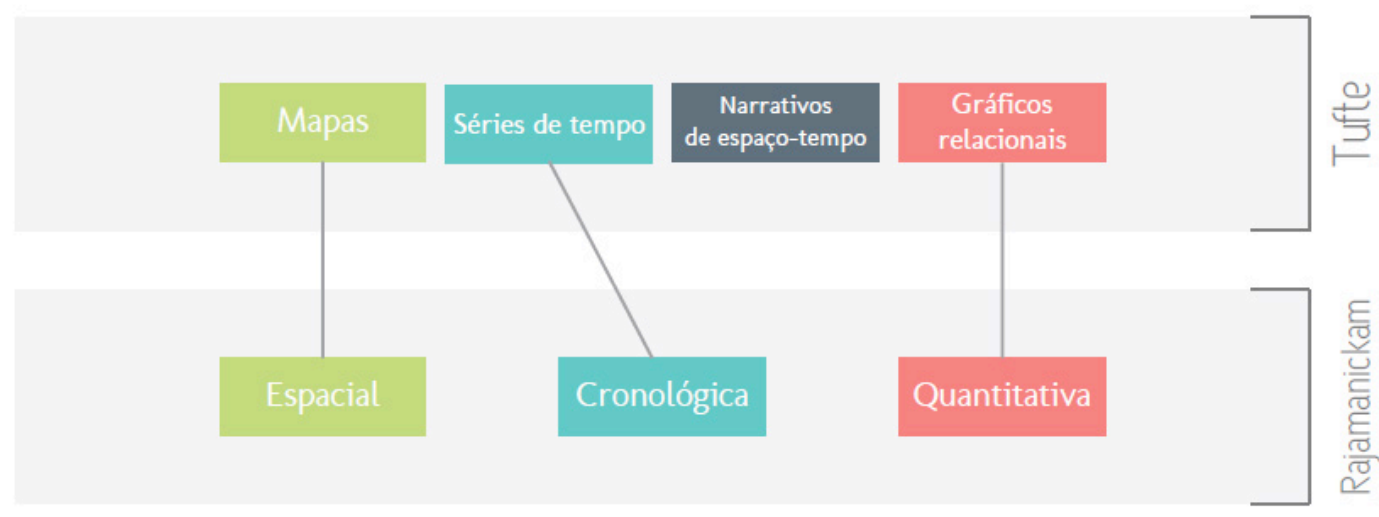

Os mapas de Tufte (2001) são comparáveis com a definição de infográficos espacias de Rajamanickam (2005), séries de tempo condizem com a cronológica e gráficos relacionais lidam com dados tanto quanto o proposto da definição do tipo de informação quantitativa. Por fim, os narrativos de espaço-tempo de Tufte (ibid.) não se relacionam com nenhuma classificação de Rajamanickam (ibid,), gerando um total de quatro tipos distintos. Aqui, serão definidas como possibilidades de conteúdo dos infográficos os tipos:

- Espacial - diz respeito a quaisquer informações ligadas à localização, sejam mapas, demais locais ou áreas de objetos.

- Cronológico - aqueles que demonstram informações sobre tempo, estático (horário, 
estações, ano, mês) ou sua passagem.

- Quantitativo - lidam com dados mensuráveis, sua exposição e/ou comparação.

- Narrativo - abordam uma sequência de acontecimentos, utilizando os tipos anteriores e/ou a combinação deles.

\section{Conceituação de infográfico sob a perspectiva do design gráfico}

$\mathrm{Na}$ revisão bibliográfica, procurou-se associar preceitos da linguagem visual às definições de infografia e classificar os elementos que compõe um infográfico. Com essas considerações, é possível definir o infográfico, levando em conta os conceitos da linguagem visual, dos gráficos e as possibilidades de seus conteúdos, gerando uma definição específica que relaciona a infografia com o design gráfico.

Infográfico é um artefato produzido no intuito de comunicar uma mensagem que compõe uma interpretação de dados quantitativos, espaciais, narrativos e/ou cronológicos, contextualizados visualmente através da integração de texto, imagens e/ou formas.

\section{Elementos do infográfico}

Tratamos o infográfico, de fato, como um artefato de linguagem visual, e para comunicar e informar visualmente, o infografista faz uso de representações gráficas como texto, imagem e forma, como nomeia Horn (1998). Para o autor (ibid.), a linguagem visual, assim como a verbal, pode ser analisada de forma sintática e semântica. A abordagem sintática dos elementos do infográfico busca enfatizar a descrição estrutural deles. Já a semântica, diz respeito a relação entre eles, e o que esta relação representa.

Este tópico abordará um pouco mais sobre os elementos que compõem infográficos, utilizando a nomenclatura sugerida por Horn (ibid.): texto, imagem e forma, através de uma abordagem semântica.

\subsection{Elementos semânticos}

Ao combinar todos os elementos da linguagem visual, geram-se peças com algum sentido. Para Horn (1998), a função semântica é o estudo da função de cada unidade de comunicação, o que cada uma pretende dizer para o leitor. No quinto capítulo de seu livro, o autor (ibid.) mostra quais funções cada unidade pode assumir. Aqui, tais funções serão conceitudas e exemplificadas com imagens feitas a partir dos exemplos contidos no livro citado.

- Mostrar "quem": Indicar pessoas envolvidas e as informações que forem relevantes sobre ela, como emoções, atitutes, identidade, etc, através da representação física da personalidade em questão, representação de algo do interesse desta pessoa e a representação de sua profissão. As três representações são feitas com imagens.

- Mostrar "o que": Indicar objeto ou local e descrever a aparência de objetos físicos. Abaixo, há três sugestões de uso, associar a imagem de um objeto com a sua descrição verbal, mostrar a aparência de algo através da exposição de suas perspectivas, utilizando imagem e forma; e, por fim, apontar uma parte do objeto, para indicar sua representação completa, fazendo uso de imagem e formas.

- Mostrar "o que há dentro": Permitir visualização do interior de objetos. Pode ser feita, por exemplo, com uma representação em perspectiva do objeto, que permita uma abertura no mesmo; com a visualização do interior através de cortes laterais, longitudinais, etc; e através da transparência de sua camada externa, representada por traços (wireframe). 
Figura 6: Exemplos das funções semânticas "mostrar quem", "mostrar o que" e "mostrar o que há dentro".

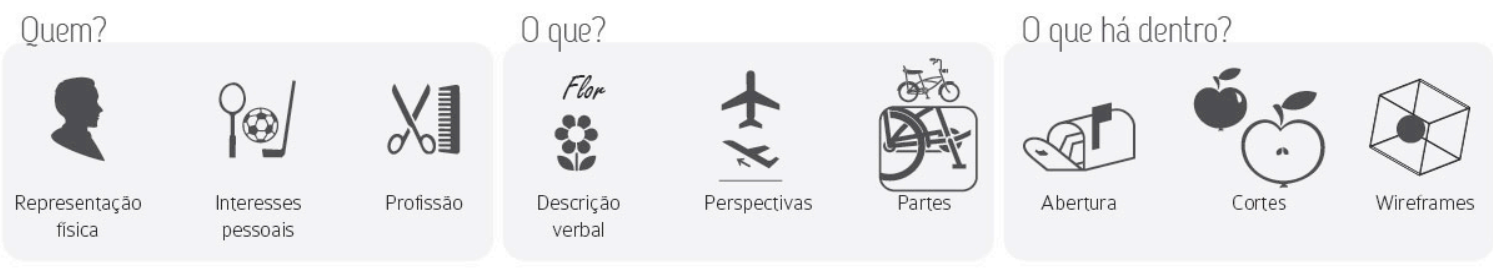

- Mostrar "onde": Dizer a localização espacial das pessoas ou objetos. Sugere-se indicar diretamente a localização, através de um mapa, por exemplo; ou através da posicão relativa entre dois objetos, representada na figura 7 por imagem, forma e texto; ou pela localização dentro de um sistema.

- Mostrar "quando": Indicar tempo. Pode ser um horário, época ou a duração de um evento. É possível representar esta função através de objetos conhecidos por determinado grupo, como o relógio; através da representação das estações; ou pela contextualização em uma linha do tempo, composta aqui por texto e forma.

- Mostrar "como funciona": Dizer o funcionamento de um sistema natural ou não, por exemplo, o funcionamento de peças dentro de um conjunto.

Figura 7: Exemplos das funções semânticas "mostrar onde", "mostrar quando" e "mostrar como funciona".

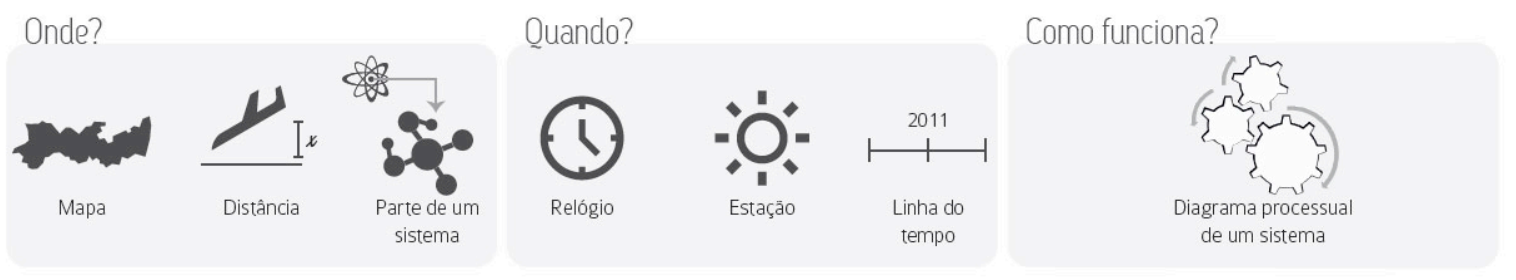

- Mostrar "como fazer": Indicar as etapas para a realização de uma tarefa. Utiliza-se a demonstração de partes da tarefa, além de passagem de etapas através de formas.

- Mostrar "movimento": Revelar mudança da localização física, que é percebida como um movimento. Sugere-se três formas de representação, através de demarcação da trajetória (com o uso de formas), da posição física do personagem ou de formas indicativas, como setas.

- Mostrar "qual": Demonstrar, indicar ou definir caracteristicas de alguma coisa. Os usos ilustrados abaixo mostram possibilidades como nomear, ressaltar um objeto através da diferença cromática ou através de sua marcação.

Figura 8: Exemplos das funções semânticas "mostrar como fazer", "mostrar movimento" e "mostrar qual".

Como fazer?

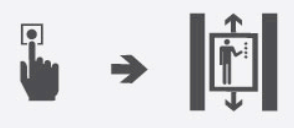

Instruçōes de uma tarefa
Movimento

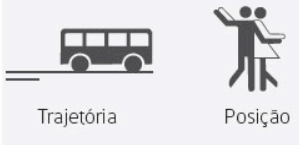

Qual?

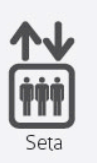

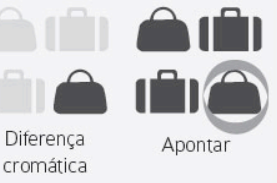

- Mostrar "exemplos": Mostrar particularidades de uma idéia geral, apontando aquilo que deseja mostrar ou ressaltar, dentro de um contexto.

- Mostrar "conceitos": Indicar forças, relações, ondas ou qualquer outro influência que não podem ser percebidas a olho nu. Nas três situações sugeridas abaixo, formas e imagens 
foram utilizadas para representar os conceitos.

- Mostrar "comparações": Dizer semelhanças e diferenças entre as coisas. O uso de tabelas pode mostrar um ou mais parâmetros de comparação. Comparações através de tamanhos também são indicadas.

- Mostrar "comparações quantitativas": Comparar visualmente dados, proporções, etc. através de gráficos, como os de barra e comparação através dos tamanhos de círculos.

Figura 9: Exemplos das funções semânticas "mostrar exemplo", "mostrar conceito", "mostrar como comparação" e "mostrar comparação quantitativa".

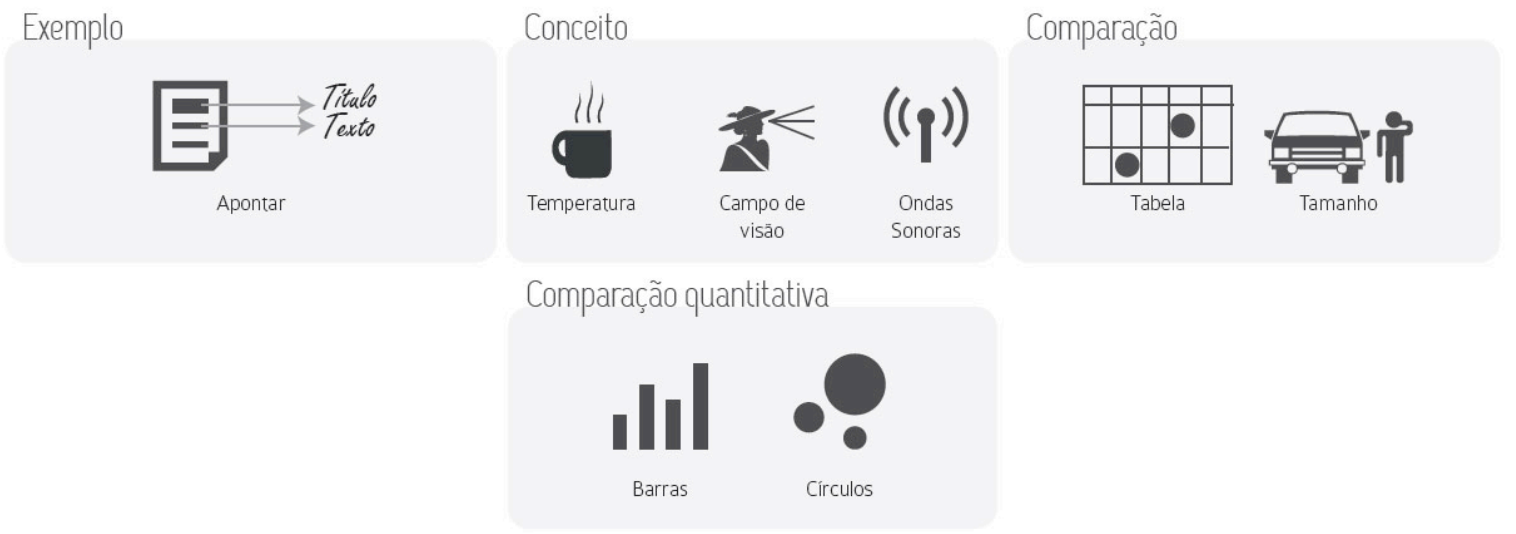

Essas funções podem ser isoladas (uma de cada vez) ou simultâneas. A partir delas e do contexto produtivo de imagens, chega-se a uma definição sobre o que é importante "mostrar" para que a informação desejada seja transmitida. Tendo desenvolvido a conceituação de infografia através dos conceitos da linguaguem visual, além de fazer um levantamento dos elementos que compõe um infográfico, finaliza-se a fundamentação teórica deste trabalho, e, portanto, a visão teórica do tema.

No próximo tópico, será explicado como foi realizada e interpretada a entrevista que, associada a esta fundamentação, resulta na proposta de uma metodologia para a criação de infográficos estáticos.

\section{A prática da infografia sob a perspectiva de profissionais ativos}

Um dos objetivos desta pesquisa é compreender a prática profissional de designers que lidam com infográficos para desenvolver uma metodologia que abarque uma visão teórica e prática sobre o tema.

Para tanto, foram entrevistados alguns infografistas brasileiros, através de um questionário capaz de apreender uma boa quantidade de informações acerca do processo produtivo dos mesmos. Algumas etapas foram seguidas, compondo uma metodologia de pesquisa:

- Entrevista piloto

- Implementação da entrevista

- Seleção de entrevistados

- Resultados

- Avaliação dos resultados

- Proposta da metodologia 


\subsection{Entrevista Piloto}

A entrevista piloto foi realizada em 26 de Maio de 2011 com Thiago Lyra - designer, infografista e ilustrador formado pela UFPE. O intuito deste piloto foi de enriquecer o conhecimento sobre a produção de infográfico e entender os aspectos relevantes para serem perguntados na pesquisa final. O entrevistado trabalhou na Revista Saúde, da Editora Abril, de 2006 até 2010, chegando a ter peça premiada no Malofiej17 (prêmio da Universidade de Navarra, Espanha) com o infográfico No rastro do $H D L$, em que as imagens contidas no infográfico são resultado da sessão fotográfica com uma maquete feita com $8 \mathrm{~kg}$ de massa de modelar (figura 10).

Figura 10: Infográfico “No rastro do HDL” publicado na Revista Saúde, em 2006.

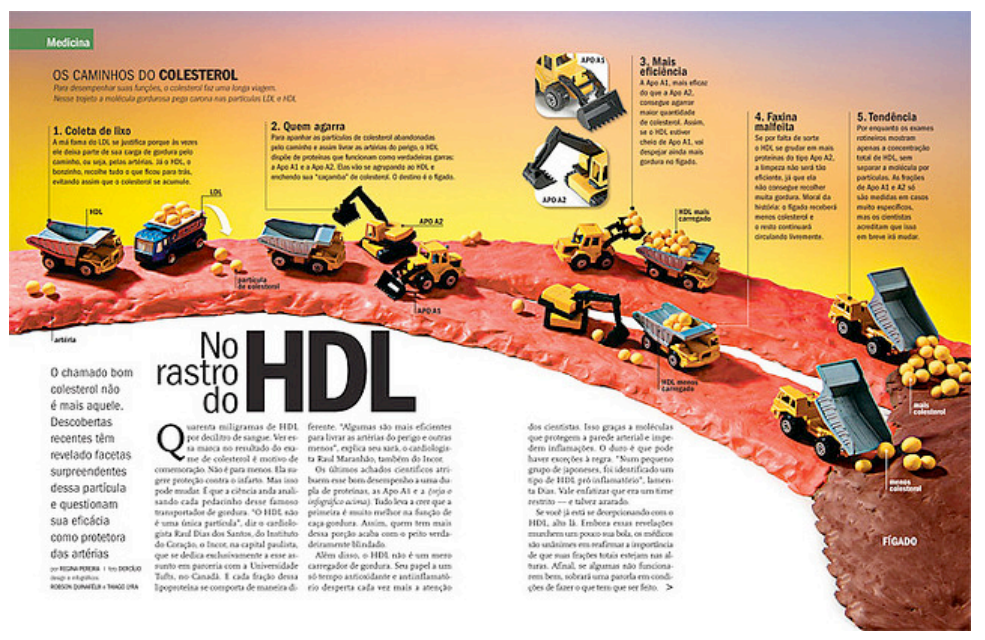

A entrevista foi feita presencialmente e contou com perguntas envolvendo três temas principais (pessoal, processo produtivo e curiosidades).

A parte pessoal incluiu perguntas sobre o envolvimento do designer com a área, sua formação e atuação profissional. Os questionamentos levantados acerca do processo produtivo abordavam a formação da equipe envolvida no projeto, como o projeto é passado para a equipe, a autonomia de edição de conteúdo, etapas do processo, utilização de elementos gráficos e influências estéticas. Finalmente, em curiosidades, o profissinal pôde pontuar certas situações ou projetos que foram mais interessantes. Foi possível observar, através da entrevista piloto, algumas falhas e acertos do questionário. $\mathrm{O}$ assunto pessoal, apesar de não ser crucial para o desenvolvimento da pesquisa, teve um viés introdutório, e mostrou-se importante.

As questões sobre processo produtivo, assunto de maior relevância para este estudo, confirmaram que perguntas mais abrangentes são mais proveitosas, pois estimulam mais a descrição. Entretanto, incluir um tópico sobre limitações técnicas aparentou ser necessário. Por fim, o tema curiosidades foi interessante, uma vez que induziu a uma conversa informal, mas não acrescentou dados novos e relevantes para a pesquisa.

\subsection{Implementação da pesquisa}

Com os resultados da entrevista piloto, chegou-se a um roteiro de entrevista mais abrangente e eficiente, composto da seguinte maneira:

\section{i. Pessoal}

Nome /ldade / Profissão e formação acadêmica

Onde trabalha/trabalhou desenvolvendo infográficos?

Para qual/quais mídias os infográficos foram produzidos? (Jornal, revista, Internet, livro, embalagem, etc.) Infografia sempre foi a área de interesse profissional?

\section{ii. Processo produtivo}

Como o conteúdo a ser explorado chega até você? 
Há liberdade de edição deste conteúdo?

Como é seu processo de desenvolvimento de infográficos?

Como são definidas/quais são as limitações técnicas?

Existem etapas definidas de desenvolvimento? Quais?

Há divisão de trabalho? (Exemplo: uma pessoa faz a arquitetura da informação, outra pessoa desenvolve os gráficos, etc.)

Como define o estilo estético do infográfico?

Existem referências estéticas inspiradoras?

Existem estilos estéticos pré-definidos?

Apesar da entrevista presencial ter se mostrado uma boa alternativa, pela possibilidade de estabelecer um diálogo entre entrevistador e entrevistado, adotá-la como padrão não seria viável. Haveria uma limitação maior de pessoas disponíveis para esse tipo de entrevista, e, consequentemente, de resultados. O meio adotado foi o digital, contando com uma entrevista online composta por um questionário que poderia ser respondido de qualquer lugar, a qualquer hora.

A ferramenta oferecida pelo Google Docs, dispõe, além de seu envio por e-mail, um espaço de visualização do questionário e do resultado dos dados obtidos em uma planilha. Atende, portanto, as necessidades da entrevista.

\subsection{Seleção dos entrevistados}

Por se tratar de uma pesquisa qualitativa com perguntas abertas, a amostra é reduzida, portanto, ficou estabelecido o número de dez entrevistados como meta, e o mínimo, de cinco entrevistas.

No primeiro momento de seleção, foi feita uma lista de contatos composta por pessoas sugeridas por Thiago Lyra, e infografistas indicados no artigo Info-Visualization Through the Eyes and Talent of 10 Brazilian Designers, publicado no site Inspired Mag. A lista incluía nomes importantes de infografistas brasileiros, profissionalmente ativos, compondo um cenário interessante para a pesquisa.

Ao todo, foi feito contato com 16 pessoas, mas apenas nove puderam contribuir com a pesquisa, número dentro do parâmetro estabelecido. O questionário foi respondido virtualmente entres os dias 09 e 23 de setembro de 2011, concluindo a fase de coleta de dados.

\subsection{Resultados}

Após a coleta de dados, iniciou-se a compilação dos mesmos. Podemos dividir as respostas dos entrevistados em resultados genéricos e individuais. Nos resultados genéricos há uma compilação de dados gerais das entrevistas, composta pelas questões complementares e numerativas. Na etapa individual foram levantados os principais pontos discutidos pelo entrevistado e ressaltadas as etapas da criação de infográficos descritas por ele.

O foco da pesquisa apresentada é de compreender o processo de produção de infográficos. Porém, faz-se necessário conhecer o perfil do grupo entrevistado. As informações de idade, formação e profissão podem fornecer uma idéia geral sobre este grupo, e foram compiladas de forma comparativa, mostrada a seguir: 
Figura 11: Gráficos de idade, formação e profissão entre os entrevistados.

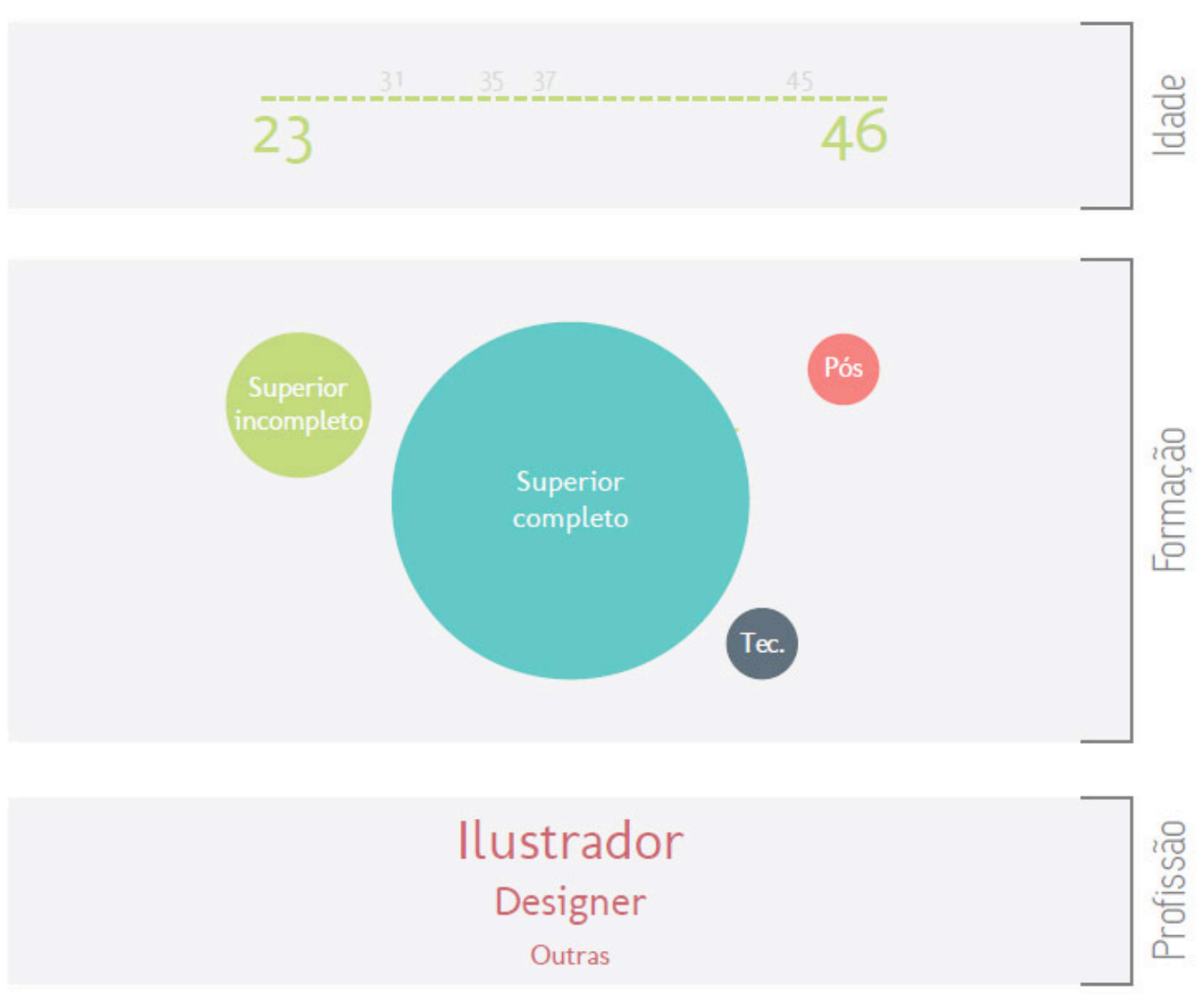

Figura 12: Gráfico de mídias citadas pelos entrevistados.

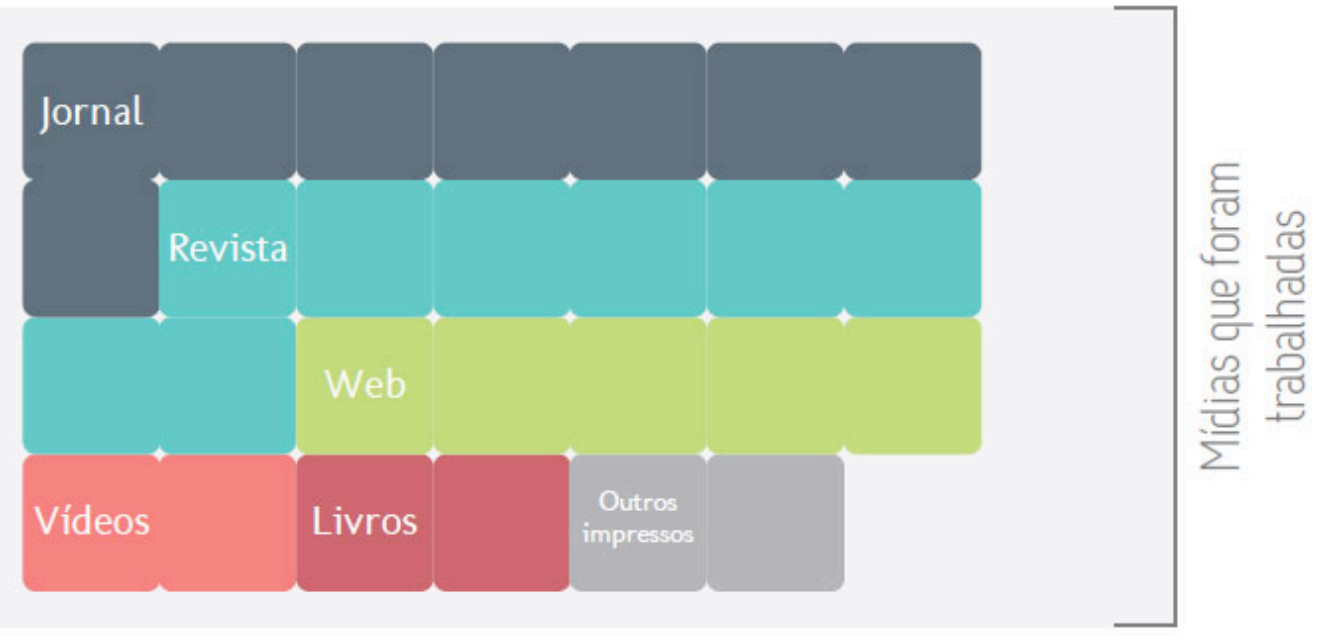

Demais dados complementares sobre a pesquisa, que ampliam a percepção do processo produtivo, vieram das questões sobre a mídia para qual os artefatos foram produzidos (Figura 12), se etapas são seguidas, se há divisão de trabalho, influências estéticas e estilos pré-definidos (Figura 13). 
Figura 13: Gráfico com resultados sobre etapas, divisão de trabalho, influências e estilos.

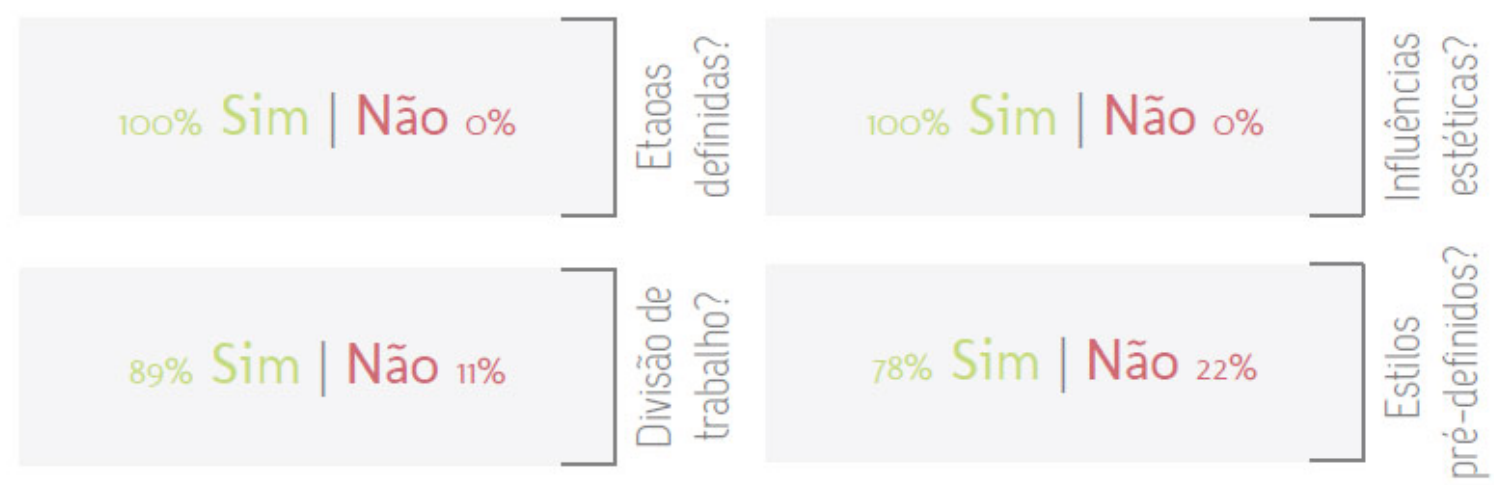

A análise individual das entrevistas foi efetuada, prioritariamente, com fim de identificar as etapas de produção dos infográficos presentes na prática profissional de cada entrevistado. Neste tópico, serão mostrados o gráfico individual de cada participante, contendo um esquema das etapas citadas pelo mesmo.

Figura 14: Entrevistados 1, 2 e 3.
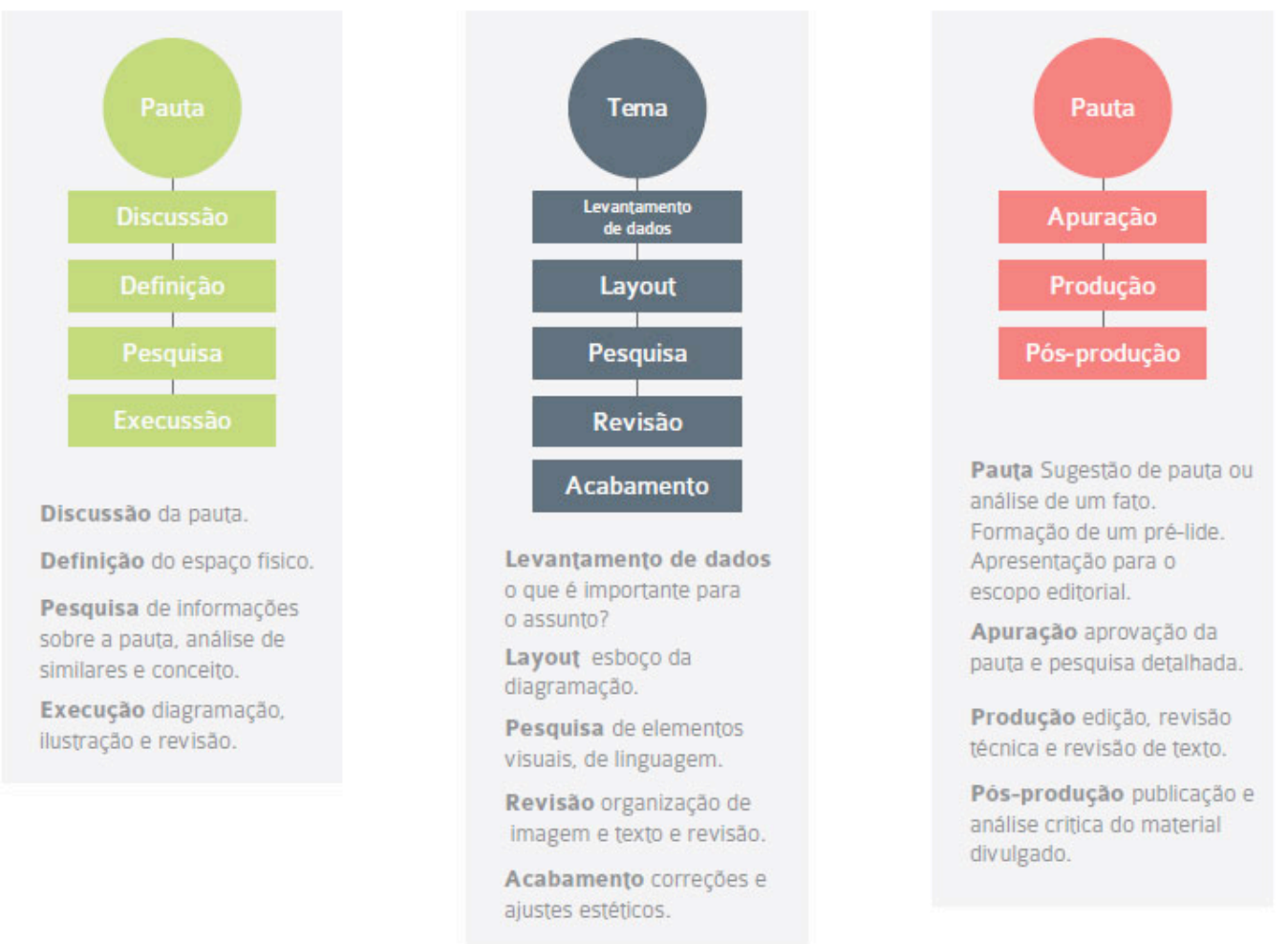
Figura 15: Entrevistados 4, 5 e 6.

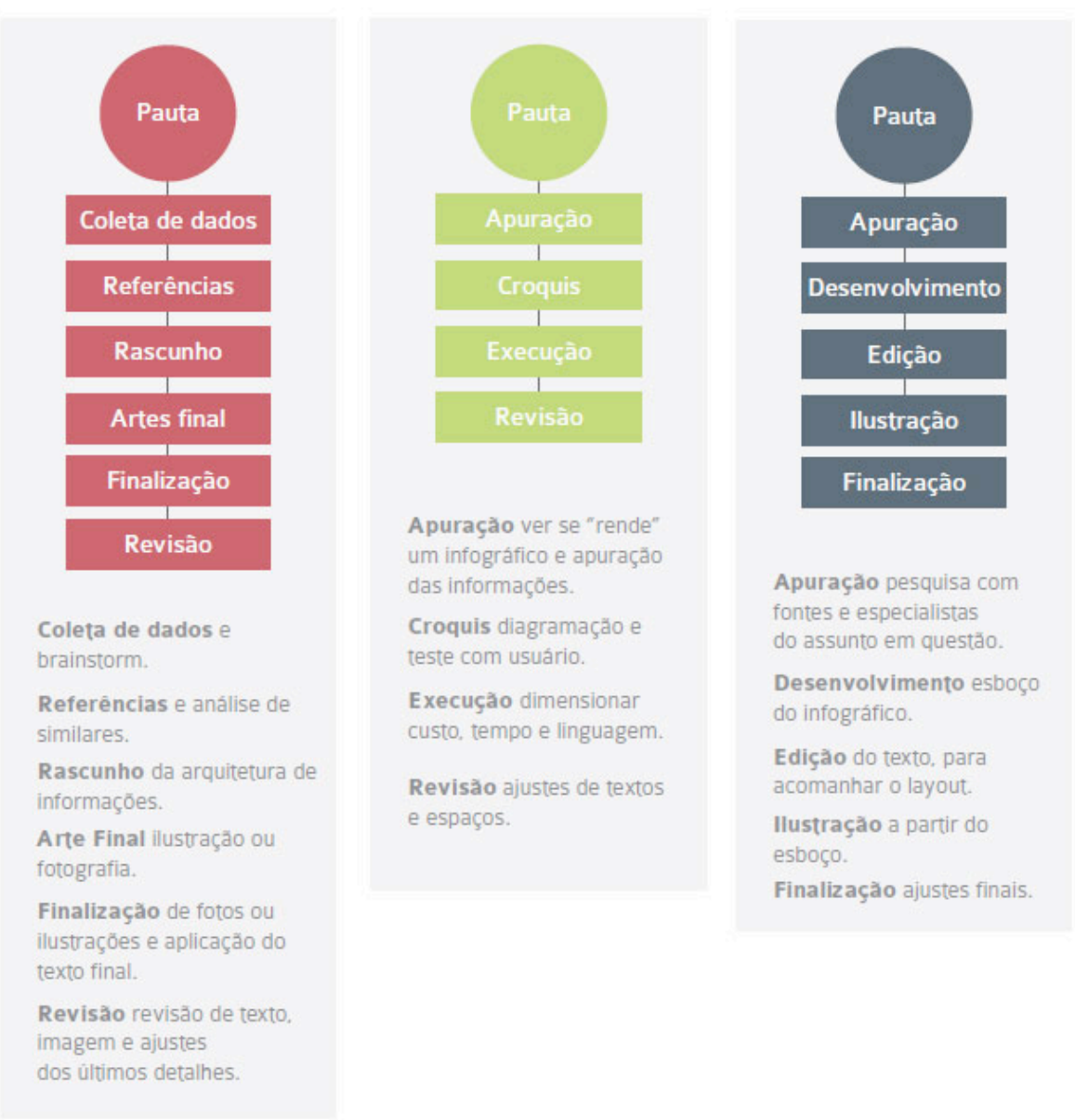

Figura 16: Entrevistados 7, 9 e 9.

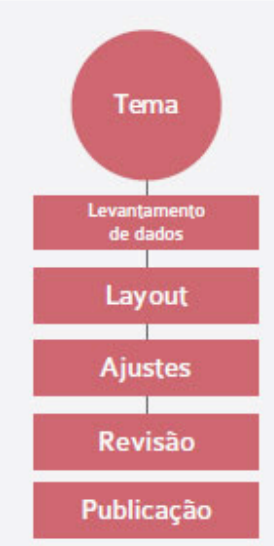

Levantamento de dados busca de informaçōes sobre o conteúdo.

Layout primeiro layout $\mathrm{e}$ desenho de página.

Ajustes juntar imagem e texto, aprovaçăo e ajustes. Revisào geral.

Publicaçào do infográfico.

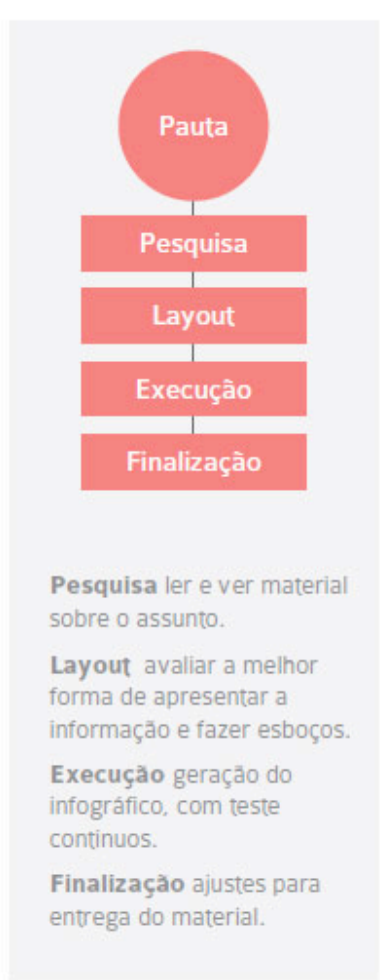

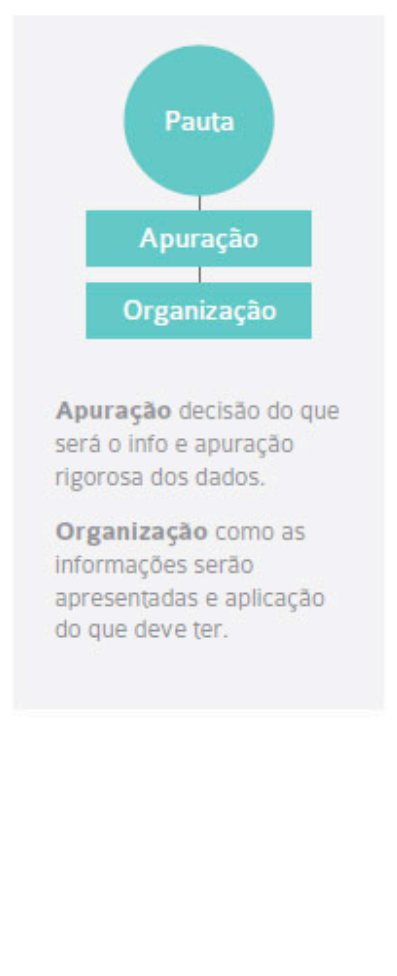




\subsection{Avaliação dos resultados}

O grupo de entrevistados mostrou certa similaridade de perfil. Em relação a idade, eles representam um público que abrange quase toda faixa etária adulta (de 23 a 46 anos). A formação é, predominantemente, superior completa, em áreas relacionadas a artes e comunicação. Essas informações indicam que se trata de uma profissão que exige certo nível de especialização.

A mídia utilizada, para publicação de infográficos nos casos coletados, foi predominantemente impressa, especialmente jornais e revistas. Demais impressos coorporativos ou livros foram pouco citados. A internet aparece com número relevante de utilização, indicando sedimentação desta plataforma.

Todos os entrevistados concordam que há etapas definidas e seguidas na produção dos infográficos. A maioria deles reconhece a necessidade de divisão de trabalho, dependendo do porte do projeto. Identifica-se, ainda, que uma pauta ou coleta de materiais para desenvolver um infográfico pode ter duas fontes: própria (no caso do infografista definir um tema e desenvolver um projeto sobre ele) ou externa (quando outro núcleo da empresa ou outra pessoa indica tema e material).

Na maioria dos casos analisados, o infográfico segue os padrões editoriais da publicação, seja de forma moderada ou extrema, e que análise de referências fazem parte do processo de criação.

Quanto às etapas de produção dos infográficos, percebemos uma grande semelhança na descrição dada pelos entrevistados. É possível, em todos os casos, obeservar três fases principais, seguidas ou não de subfases: concepção, execução e acabamento. Esta regularidade denota que há estabelecido uma maneira de produção, uma ordem natural, que precisa ser levada em consideração para a construção da metodologia.

A análise das etapas partiu da comparação entre os gráficos desenvolvidos para os resultados da entrevistas (figuras 14, 15 e 16). Fases com nomes distintos, mas com mesma função, foram consideradas como uma só, por exemplo, "pauta" e "tema" apareceram como termos que definem o recebimento ou a criação de um assunto para ser tratado no infográfico. Layout, esboço e rascunho, dizem respeito à etapa de geração de alternativas e testes de diagramação/arquitetura da informação, e assim por diante. Desta comparação, foi possível definir as etapas da metodologia proposta neste trabalho.

\section{Proposta de Metodologia}

Propõe-se aqui a metodologia de produção de infográficos baseada nas etapas descritas nas entrevistas (visão prática) e na própria revisão bibliográfica feita a partir dos fundamentos do design gráfico (visão teórica). As entrevistas foram comparadas e compiladas em um único esquema, já o referencial trouxe fundamentos para algumas etapas. A metodologia proposta neste artigo pode ser dividida em três fases: concepção, execução e acabamento.

A fase de concepção compreende etapas de definição e apropriação do tema que será abordado na peça. Nelas, o mais importante é compreender o assunto do artefato e o que é importante transmitir sobre ele. Agrega-se, aqui, as variáveis de produção de Twyman (1985), que aborda questões relevantes sobre público alvo, entre outros.

Durante a execução, há elaboração de conteúdo e arquitetura da informação. Considera-se importante para esta fase o conteúdo estudado na fundamentação teórica sobre elementos do infográfico (Horn, 1998). A partir deste entendimento, há um melhor embasamento para hierarquizar informações e compor os elementos gráficos.

Por fim, na fase de acabamento, há etapas de união de texto e projeto gráfico, ajustes, revisões e análise crítica sobre o infográfico. Nela, junta-se forma e conteúdo do infográfico e cuida-se dos detalhes de produção do mesmo. A seguir as etapas da metodologia: 
Figura 17: Proposta de metodologia para infográfico estáticos

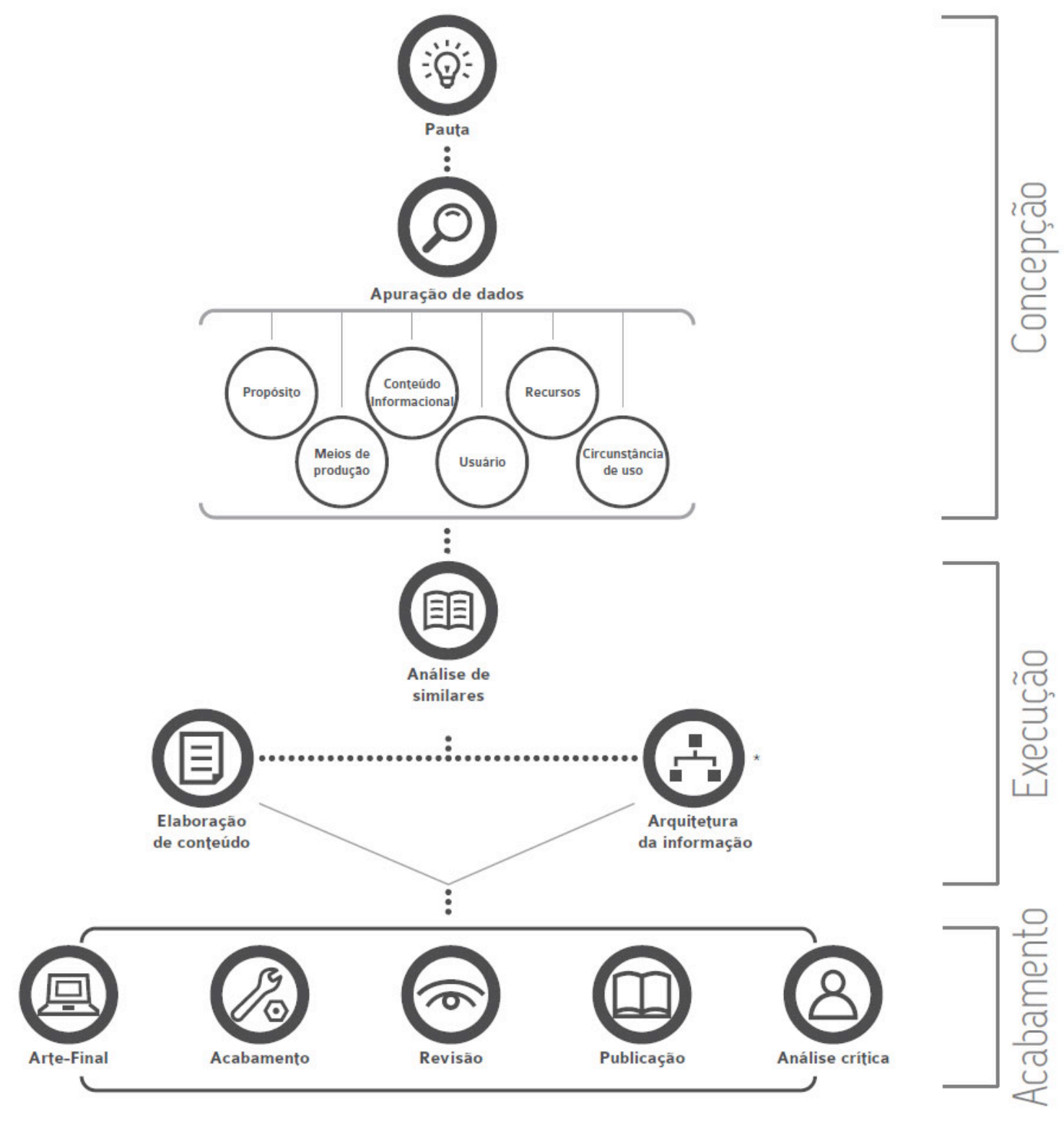

\subsection{Pauta}

O infográfico tem início com a sugestão de uma tema a ser discutido e publicado. Pode ser um tema de estudo, um fato ou uma notícia. Tal tema deve ser relevante para determinada publicação e/ou público.

\subsection{Apuração e levantamento de dados}

Definido o tema, parte-se para a pesquisa do que e como o conteúdo deve ser exposto. Propõe-se aqui o uso das variáveis do contexto produtivo de imagens, desenvolvido por Twyman (1985). As variáveis de criação propostas por Twyman (ibid.) se adequam perfeitamente à proposta de desenvolvimento de infográficos, por considerar o objeto para o qual está sendo produzido e para que tipo de usuário:

- Propósito: Qual o objetivo do infográfico? O que se deseja transmitir ao leitor?

- Conteúdo informacional: Quais informações são necessárias para realizar o objetivo? 
- Recursos: Avaliação de tempo, verba, profissionais disponíveis, além de outras limitações, como mídia, cores, etc.

- Meio de produção: Como será desenvolvido? llustração? Fotografia? Em quais softwares?

- Usuários: Para quem é destinado o infográfico?

- Circunstâncias de uso: Em qual mídia será vista, e como será vista a publicação?

\subsection{Análise de similares}

Nesta fase, buscam-se referências do que já foi feito com o tema em questão, além de inspirações estéticas.

\subsection{Elaboração de conteúdo}

Após avaliação daquilo que deve ser transmitido, elabora-se o conteúdo informacional: a parte textual.

\subsection{Arquitetura de informação}

Concluídas as etapas anteriores, inicia-se o processo de organizar as informações no espaço disponível. São esboços que podem ser feitos manual ou digitalmente com os elementos que precisam constar no layout.

- Texto: Título, abertura, subtítulo e legenda.

- Imagem: Representação de algo real ou imaginado. Pode indicar: Quem, o que, o que há dentro, onde, quando, como funciona, como fazer, movimento, qual, exemplos, conceitos, comparações e comparações quantitativas.

- Forma: Quais formas são importantes para a integração de texto e imagem? Ponto, linha, formas abstratas, espaço entre formas.

Nesta etapa, o infografista deve usar como referência os elementos gráficos apresentados acima (item 3.2). Também é indicado realizar testes com leitores, a fim de confirmar a legibilidade e leiturabilidade das informações.

\subsection{Arte-final}

Fase na qual o esboço é convertido para peça finalizada, ilustrações ganham cores e estilos, fotografias são produzidas, textos e formas ganham propriedades, etc.

\subsection{Acabamento}

Realização de ajustes da integração entre texto, imagens e/ou formas. Tamanho de legendas, e demais ajustes são realizados.

\subsection{Revisão}

Revisão final do artefato. Se necessário, realizam-se novos ajustes.

\subsection{Publicação}

Envia-se o infográfico para a produção, onde será publicado na mídia: internet, jornal, revista, livro, etc.

\subsection{Análise crítica}


Após publicado, é recomendado fazer uma análise dos pontos positivos e negativos do processo, no intuito de gerar aprendizagem.

\section{Considerações Finais}

Nesta pesquisa procuramos conhecer referenciais teóricos sobre infográficos e design gráfico (Rajamanickam, 2001; Horn, 1998; Twyman, 1979) com finalidade de associar preceitos da linguagem visual às definições de infografia. Dessa forma, buscamos entender os elementos que compõe um infográfico, analisando-os sintática e semanticamente. A conceituação alcançada e as análises do elementos do infográfico compõe um conjunto de informações relevantes para a visão prática desta pesquisa e a área da infografia.

Com as entrevistas e com os estudos realizados na fundamentação desta pesquisa, foi possível propor uma metodologia para criação de infográficos coerente com a prática profissional contemporânea de profissionais da área. Esta contém dez etapas, que podem ser agrupadas em três fases: concepção, execução e acabamento. Convém ressaltar o caráter sugestivo desta metodologia, que pode e deve ser testada e editada de acordo com cada projeto.

\section{Referências}

DE PABLOS, Jose Manuel. 1999. Infoperiodismo. El Periodista como Creador de Infografia. Madrid: Editorial Sintesis.

HORN, Robert E. 1998. Visual Language: Global communication for the 21st Century, Washington: Macro VU, Inc.

MEGGS, Philip B. 1983. A History of Graphic Design. London: Alan Lane.

RAJAMANICKAM, Venkatesh. 2005. Infographics Seminar Handout. Disponível em <http://www.albertocairo.com/infografia/noticias/2005/infographichandout.pdf $>$. Acesso em 8 de Junho de 2011.

RIBEIRO, Susana Almeida. 2008. Infografia de Imprensa: História e análise ibérica comparada. Minerva Coimbra.

TUFTE, Edward R. 1983. The Visual Display of Quantitative Information. Cheshire, Connecticut: Graphics Press.

TWYMAN, Michel. 1979. A schema for the study of graphic language. In: Paul A. Kolers, Merald E. Wrolstad; Herman Bouma (Ed.). Processing of visible language. Nova York \&Londres: Plenum Press.

TWYMAN, Michael. 1985. Using pictorial language: a discussion of the dimensions. In: Dufty, Thomas M. \& Waller, Robert (Ed.). Designing usable text. Orlando, Florida: Academic Press, pp.245-312.

\section{Sobre os autores}

Juliana Carvalho, Bacharel em Design pela UFPE.

<julianagc@gmail.com>

Isabella Aragão, Doutoranda em Arquitetura e Urbanismo pela FAU USP, professora assistente do departamento de Design da UFPE.

<isabella.aragao@gmail.com>

[Artigo recebido em dezembro de 2012, aprovado em dezembro de 2012] 